\title{
Non-commutability of results of highly sensitive troponin I and T immunoassays
}

\author{
Giuseppe Lippi ${ }^{*}$, Gianfranco Cervellin², Rosalia Aloe ${ }^{1}$, Martina Montagnana ${ }^{3}$, Gian Luca Salvagno ${ }^{3}$, Gian Cesare Guidi ${ }^{3}$ \\ ${ }^{1}$ U.O. di Diagnostica Ematochimica, Azienda Ospedaliero-Universitaria di Parma, Parma, Italy \\ 2U.O. di Pronto Soccorso e Medicina d'Urgenza, Azienda Ospedaliero-Universitaria di Parma, Parma, Italy \\ ${ }^{3}$ Sezione di Biochimica Clinica, Dipartimento di Scienze della Vita e della Riproduzione, Università degli Studi di Verona, Verona, Italy \\ *Corresponding author: glippi@ao.pr.it, ulippi@tin.it
}

\begin{abstract}
Introduction: The measurement of cardiospecific troponins is pivotal in the diagnostic and prognostic approach of patients with suspected acute myocardial infarction (AMI). However, no information is available on the commutability of results between the novel highly-sensitive (HS) troponin $\mathrm{T}$ (TnT) and I (Tnl) immunoassays.

Materials and methods: The study population consisted in 47 consecutive patients presenting at the emergency department (ED) of the Academic Hospital of Parma with suspected AMI. Tnl was measured with the novel prototype Beckman Coulter HS-AccuTnl immunoassay on Access 2, whereas InT was measured with the Roche HS-TnT immunoassay on Cobas.

Results: Eight out of the 47 patients (17\%) were finally diagnosed as having an AMI. The overall correlation between TnT and Tnl for total patient group was acceptable $(r=0.944 ; \mathrm{P}<0.01)$. Nevertheless, when the analysis of data was carried out in separate groups according to the final diagnosis of AMl, two different equation results were obtained, i.e., HS-TnT $=$ HS-AccuTnl x $0.349+20(r=0.823 ; \mathrm{P}<0.01)$ in non-AMl patients, and HS-TnT $=$ HS-AccuTnl x $0.134+67(r=0.972 ; P<0.01)$ in those with AMl.

Conclusions: This study suggests the existence of two biological relationships between $\mathrm{Inl}$ and $\mathrm{TnT}$ in plasma, depending on the source of release from the myocardium. Moreover, the non-commutability of data between HS-InT and HS-AccuTnl jeopardizes the clinical decision making, makes it impossible to calculate the delta or reference change value using the two biomarkers and to finally establish a reliable kinetics of troponin release from the injured myocardium.
\end{abstract}

Key words: troponin; biological markers; commutability; myocardial infarction

\section{Introduction}

The measurement of cardiospecific troponins is a mainstay in the diagnostic and prognostic approach of patients with suspected acute myocardial infarction (AMI). Reliable evidence has been gathered about an excellent correlation between the upper measuring range of the new, highly sensitive (HS) Troponin T (TnT) immunoassay and the values obtained for the former $4^{\text {th }}$ generation immunoassay (1). No information has however been provided on the commutability of results between TnT and troponin I (Tnl) immunoassays, to the best of our knowledge. Therefore, the aim of this study was to compare the data obtained by the Roche highly sensitive Troponin T (HS-TnT) (Roche Diagnostics $\mathrm{GmbH}$, Basel, Switzerland) and the novel prototype HS-AccuTnl (Beckman Coulter Inc., Brea CA, USA) immunoassays in patients admitted at the emergency department (ED) with suspected AMI.

\section{Materials and methods}

The study population consisted in 47 consecutive patients presenting at the ED of the Academic Hospital of Parma with suspected AMI over one 
week, from the $13^{\text {th }}$ to the $20^{\text {th }}$ of June, 2011. Samples were immediately collected on patient admission in vacuum tubes without additive, centrifuged at room temperature and $1500 \times \mathrm{g}$, and immediately tested. Tnl was measured with the novel prototype HS-AccuTnl immunoassay, on Access 2 (Beckman Coulter Inc.). The $99^{\text {th }}$ percentile reference limit, the optimal imprecision (i.e., total coefficient of variation $\leq 10 \%$ ), and limit of detection (LOD) are $8.6 \mathrm{ng} / \mathrm{L}, 8.6 \mathrm{ng} / \mathrm{L}$ and $2.1 \mathrm{ng} / \mathrm{L}$ (2). TnT was measured with the Roche HS-TnT immunoassay on Cobas (Roche Diagnostics $\mathrm{GmbH}$ ). The $99^{\text {th }}$ percentile reference limit, the optimal imprecision and LOD are $14.0 \mathrm{ng} / \mathrm{L}, 13.0 \mathrm{ng} / \mathrm{L}$ and $2.0 \mathrm{ng} / \mathrm{L}$ (3). Results were finally expressed as median and $95 \%$ Confidence Interval $(95 \% \mathrm{Cl})$. The results of HS-TnT and HS-AccuTnl immunoassays were analyzed by linear regression analysis and Pearson correlation coefficient (r).

\section{Results}

Eight out of the 47 patients (17\%) were finally diagnosed as having an AMI, according to the established criteria (4). The final diagnosis for each patient was achieved by two independent cardiologists who reviewed all available medical records and results of laboratory tests. The median values (95\% Cl) of HS-TnT and HS-AccuTnl were $31 \mathrm{ng} / \mathrm{L}$ (3-240 ng/L) and $95 \mathrm{ng} / \mathrm{L}$ (5-534 ng/L) in patients without $\mathrm{AMI}$, and $651 \mathrm{ng} / \mathrm{L}$ (323-1429 ng/L) and $5568 \mathrm{ng} / \mathrm{L}$ (1543-10276 ng/L) in those with AMI. The overall correlation of all test results was $r=0.944$ ( $P$ $<0.001)$, and the relative equation was HS-TnT = HS-AccuTnl x 0.138 [95\% Cl (0.130-0.145)] + 41 [95\% $\mathrm{Cl}$ (21-61)]. Nevertheless, when the analysis of data was carried out in separate groups according to the final diagnosis of AMI (i.e., AMI N = 8; and nonAMI N = 39), two different results were observed. In particular, in the non-AMI group the correlation coefficient was $0.823(P<0.001)$ and the equation HS-TnT = HS-AccuTnl x 0.349 [95\% Cl (0.268-0.429)] +20 [95\% Cl (6-34)], whereas in the AMI group the correlation was higher $(r=0.972 ; P<0.001)$, and the equation was also significantly different, i.e., HS-TnT = HS-AccuTnl x 0.134 [95\% Cl (0.102-0.166)] +67 [95\% Cl (-142-277)].

\section{Discussion}

This is the first investigation assessing the correlation of HS-TnT with the novel HS-AccuTnl in patients with and without AMI, to the best of our knowledge. In the latter category of patients, this was especially allowed by the remarkably improved analytical sensitivity of these novel methods. Although our study is relatively small, the results attest that two rather different biological relationships exist between $\mathrm{Tnl}$ and $\mathrm{TnT}$ in plasma, depending on the source of release of these proteins from the myocardium. In the former instance, which is characterized by the physiological renewal of the cardiomyocytes or mechanical stretch of cardiomyocytes due to pressure or volume overload in subjects without AMI (5), the concentration of TnT in plasma is nearly one third of that of Tnl. Conversely, after irreversible ischemic myocardial injury and necrosis, the concentration of $\mathrm{Tnl}$ in plasma becomes nearly 10-time higher than that of TnT. It is thereby misleading to perform correlation analysis after mixing AMI cases and controls. This observation has also important clinical implications. Due to the increasing diffusion of the "hub and spoke" network model in healthcare, which is also characterized by centralization of intensive

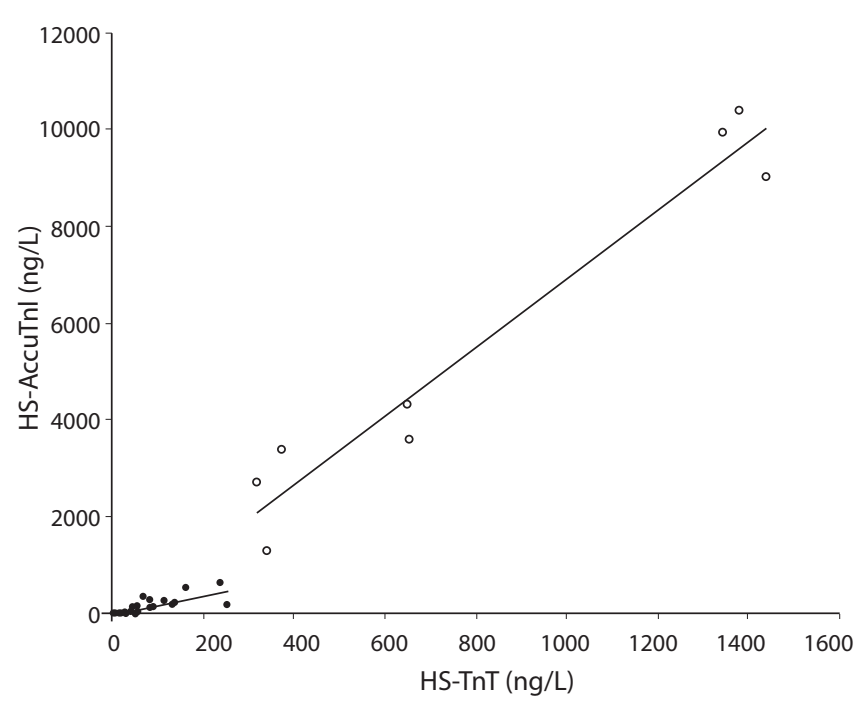

FIGURE 1. Linear regression analysis and correlation between results of highly sensitive (HS) troponin $\mathrm{T}(\mathrm{TnT})$ and I (Tnl) in 47 patients admitted to the emergency department with suspected acute myocardial infarction (AMI). ( non-AMI, N = 39; $\mathrm{AMI}, \mathrm{N}=8$ ). 
therapy/intensive treatment cardiology units (6), the first sample for troponin testing might be drown in a peripheral ED, from where critical patients might then be transferred to the reference hospital of the area. Since in several national settings the peripheral and the core laboratories might use different troponin immunoassays (i.e., HS-Tnl versus HS-TnT), our results clearly attest that the non-commutability of data jeopardizes the

\section{References}

1. Bertsch T, Braun SL, Giannitis E, Knebel F, Weber M, Christ M. Conference on clinical use of troponin Thigh sensitive (TnThs) on September 8, 2009 at the airport conference center, Frankfurt/Main. Clin Lab 2010;56:355-8.

2. Kavsak PA, MacRae AR, Yerna MJ, Jaffe AS. Analytic and clinical utility of a next-generation, highly sensitive cardiac troponin I assay for early detection of myocardial injury. Clin Chem 2009;55:573-7.

3. Reichlin T, Hochholzer W, Bassetti S, Steuer S, Stelzig C, Hartwiger S, et al. Early diagnosis of myocardial infarction with sensitive cardiac troponin assays. $N$ Engl J Med 2009;361:858-67.

4. Thygesen K, Alpert JS, White HD, on behalf of the Joint ESC/ ACCF/AHA/WHF Task Force for the redefinition of myocardial infarction. Universal definition of myocardial infarction. J Am Coll Cardiol 2007;50:2173-95. clinical decision making based on results of different immunoassays and, even more importantly, makes it impossible to calculate the delta or reference change value between the first and the following troponin results (7), and finally establish a reliable kinetics of troponin release from the injured myocardium.

\section{Potential conflict of interest}

None declared.

5. Giannoni A, Giovannini S, Clerico A. Measurement of circulating concentrations of cardiac troponin I and T in healthy subjects: a tool for monitoring myocardial tissue renewal? Clin Chem Lab Med 2009;47:1167-77.

6. Ugolini C, Nobilio L. Vertical integration and contractual network in the cardiovascular sector: the experience of the Italian region Emilia Romagna. Int J Integr Care 2003;3:e20.

7. Introcaso G, Raggi M, D'Errico T, Cavallero A. Short-term increases of plasma cardiac troponin I are better evaluated by comparison with the reference change value. Biochem Med 2010;20:327-33.

\section{Jesu li rezultati dobivenih visoko osjetljivim imunokemijskim testovima za određivanje koncentracije troponina I i T međusobno zamjenjivi?}

\section{Sažetak}

Uvod: Određivanje koncentracije srčano-specifičnog troponina predstavlja osnovni dijagnostički i prognostički pristup bolesnicima sa suspektnim akutnim infarktom miokarda (engl. acute myocardial infarction, AMI). Međutim ne postoje podaci o međusobnoj zamjenjivosti rezultata između novih visoko osjetljivih imunokemijskih testova za određivanje koncentracije troponina T (HS-InT) i troponina I (Tnl).

Materijali i metode: Populaciju ispitanika činilo je 47 uzastopnih bolesnika primljenih u hitnu službu (engl. emergency department, ED) Akademske bolnice u Parmi sa sumnjom na akutni infarkt miokarda. Koncentracija Inl određena je novim prototipom imunokemijskog teksta HSAccuTnl od tvrtke Beckman Coultera na analizatoru Access2, dok je koncentracija TnT određena imunokemijskim testom HS-TnT tvrtke Roche Diagnostics na analizatoru Cobas.

Rezultati: Za osam od 47 (17\%) bolesnika naposljetku je postavljena dijagnoza AMI. Ukupna korelacija između TnT i Tnl za sve ispitanike bila je prihvatljiva $(r=0,944 ; \mathrm{P}<0,01)$. Međutim, nakon izvršene analize podataka u odvojenim skupinama prema završnoj dijagnozi AMI, dobivene su dvije različite jednadžbe rezultata: HS-InT $=$ HS-AccuInl x 0,349 $+20(r=0,823 ; \mathrm{P}<0,01)$ za ispitanike bez dijagnoze AMI i HS-InT $=$ HS-AccuTnl $\mathrm{x} 0,134+67(\mathrm{r}=0,972 ; \mathrm{P}>0,01)$ za ispitanike s dijagnozom AMI.

Zaključak: Rezultati istraživanja upućuju na postojanje dvije biološke veze između Tnl i TnT u plazmi, ovisno iz kojeg djela miokarda dolazi. Štoviše, nemogućnost zamjene rezultata dobivenih testovima za HS-TnT i HS-AccuInl ugrožava kliničko donošenje odluka te onemogućuje izračunavanje promijene vrijednosti (delta) ili klinički značajne promjene koncentracije primjenom ova dva biološka biljega te onemogućuje konačnu izradu pouzdane kinetike otpuštanja troponina iz ozlijeđenog miokarda.

Ključne riječi: troponin; srčani biološki biljeg; zamjenjivost; akutni infarkt miokarda 